\title{
Indigenous peoples and the morality of the Human Genome Diversity Project
}

Michael Dodson and Robert Williamson University of New South Wales, Sydney and The Murdoch Institute Royal Children's Hospital, Melbourne, Australia

\begin{abstract}
In addition to the aim of mapping and sequencing one human's genome, the Human Genome Project also intends to characterise the genetic diversity of the world's peoples. The Human Genome Diversity Project raises political, economic and ethical issues. These intersect clearly when the genomes under study are those of indigenous peoples who are already subject to serious economic, legal and/or social disadvantage and discrimination. The fact that some individuals associated with the project have made dismissive comments about indigenous peoples has confused rather than illuminated the deeper issues involved, as well as causing much antagonism among indigenous peoples. There are more serious ethical issues raised by the project for all geneticists, including those who are sympathetic to the problems of indigenous peoples. With particular attention to the history and attitudes of Australian indigenous peoples, we argue that the Human Genome Diversity Project can only proceed if those who further its objectives simultaneously:

- respect the cultural beliefs of indigenous peoples; - publicly support the efforts of indigenous peoples to achieve respect and equality;

- express respect by a rigorous understanding of the meaning of equitable negotiation of consent, and

- ensure that both immediate and long term economic benefits from the research flow back to the groups taking part.
\end{abstract}

(Fournal of Medical Ethics 1999;25:204-208)

Keywords: Indigenous peoples; Aboriginal; Human Genome Project; cultural beliefs; consent; HGDP

\section{The Human Genome Project}

The Human Genome Project (HGP) is funded jointly by the Department of Energy and the National Institutes of Health in the United States, by many other government agencies worldwide, and by private biotechnology companies. Its objectives (in order) are to map the human genome, to determine the sequences of the $2-3 \%$ of the genome which codes for proteins, and then to determine the entire human DNA sequence (three billion base pairs per haploid [sperm or egg] genome). It is likely that these objectives wit be realised by the year $2001 .^{1}$

Although the HGP has a monumental vision of its own, it should be noted that many of its com ponent parts, particularly those related to specific diseases such as cancer and cystic fibrosis, wene already well funded prior to the establishment of the HGP. These preexisting targeted research programmes were integrated into the HGP at its inception, and for some years provided the bas for most scientific advances. However, a variety of random ordering and sequencing strategies (sucto as those which used a set of large families to may random sequences, or sequenced all coding genes (ESTs), or randomly sequenced the ends of human DNA fragments cloned in bacterial artifi cial chromosomes (BACs)) proved to be les elegant but more effective.

The diseases that affect most people are not duf to inherited mutations in single genes, but involve the interactions of several gene variants with eac耳 other and with environment. This is the case for cancer, heart disease, Alzheimer's diseases diabetes, and even susceptibility to infection. It also true for behavioural traits (such as aggressiog and alcoholism) and psychiatric illness. The diseases are very important to all communitie? and also very attractive as targets both to established pharmaceutical companies and to new biotechnology companies. Even if one does nof accept a facile reductionist approach to multifac torial diseases, a genetic approach often yields clues as to which pathway is involved, which ig turn suggests pharmacological interventiong which could be extremely profitable.

\section{The Human Genome Diversity Project}

When the Human Genome Project started, the question "whose genome should be sequenced? was asked many times. While all human genomes have overwhelming similarities (particularly in the order in which the genes occur), there are mang differences in sequence, approximately five mif lion between any two individual haploid genomes Because these differences are responsible for pret. 
disposition to some diseases as well as normal variation, and can be used for anthropological and genealogical research, there was immediate interest in extending the genome project to collect and to sequence DNA samples from many different human groups. ${ }^{23}$

Indigenous peoples were identified as among the groups to be especially targeted for genome studies. ${ }^{4}$ Some of the early proposals included comments from the protagonists which could be described politely as naive in the extreme. Indigenous peoples felt they were being treated as examples of human fossils, from whom samples had to be collected before they died out. Remarks such as this, which were widely quoted, led to the characterisation of the Human Genome Diversity Project (HGDP) as the "vampire project" and are still greatly resented by indigenous peoples. ${ }^{6}$ However, for the purposes of this article we wish to put these remarks to one side, as their offensiveness distracts from a sensible analysis of the underlying issues that are involved for all scientists and all indigenous peoples.

Indigenous peoples do not suffer from the same diseases in the same ratios as do North Europeans. This is partly a result of poverty, but it also is due to genetic differences which cause interactions with environment leading to health outcomes. These are not always bad outcomes - for instance, although the incidence of heart disease, hypertension and diabetes is high amongst Australian Aboriginal peoples, the incidence of some types of cancer is relatively low.

One of the main objectives of studies of the genomes of indigenous peoples is to determine gene sequences that may confer these "positive" and "negative" differences. In this way, it is hoped that greater understanding of underlying causes of pathology will lead to new methods for treatment. Pharmaceutical and biotechnology companies wish to ensure that any discoveries are patented to protect their investment.

However, there are several practical problems, apart from the ethical ones dealt with in the following sections. It was once thought that there were many unique DNA differences between different racial or ethnic groups. For several reasons, this is not true. First, most groups (of any kind) overestimate their genetic "purity"; there is usually more genetic intermixture between groups than is appreciated culturally. (For instance, in Cyprus the Greek and Turkish communities think of themselves as very separate, but share almost all allelic variants of every gene that has been studied.) Second, there are few differences between ethnic or racial groups which can identify a community unambiguously; sophisticated hap- lotype constructs have to be studied to reveal such differences. Finally, there are problems in defining phenotype if the relationship between genotype and environment is confused - although there appears to be a very high incidence of alcoholism among Aboriginal men, it was only after colonisation of Australia that alcohol became widely available, and there was no alcoholism in traditional Aboriginal society.

\section{The history of indigenous peoples, their cultures and their interactions with colonising peoples}

There are hundreds, perhaps thousands, of different indigenous peoples, and it would be foolish to attempt to overstate the generalisations that can be made amongst them. However, a few points can be made which are useful in this context.

1. For whatever reason (whether cultural or economic), most indigenous peoples did not develop a society where goods were seen as primarily the property of individuals, to be bought and sold without reference to the group as a whole. Land and other property are often seen as belonging to the group (nation, or tribe, or extended family), and either cannot be bought and sold at all, or can only be sold if the entire group agrees to this after discussion. This extends to "genetic property" such as DNA.

2. Culture is seen in a more historical way than in many Western countries, extending backwards and forwards in time infinitely. Maintenance of traditions may be of much greater importance than present events, and the extended family may be of greater importance than the nuclear family.

3. Culture is far more likely to be regarded as a group or tribal property, rather than belonging to an individual, and the individual will not have the right to offer cultural or human values or samples from the group any more than other property, such as land. This may well apply to blood or tissue, which is usually treated with cultural respect as part of the inheritance of the group.

In many indigenous cultures, an individual will not have the right to give or sell a blood sample for gene testing to a researcher without the consent of the group (and perhaps not at all). It would be regarded as an invalid contract with profound ethical implications (perhaps comparable in "Western" law to the prohibitions on a father selling his six-yearold daughter as a child prostitute, something we 
would regard as ethically outrageous in an autonomy-centred individualist society.)

These cultural beliefs are deeply held and not dependent on a history of deprivation and discrimination. Superimposed upon these beliefs is the fact that most indigenous peoples are living in poverty compared to those who colonised their countries. This poverty is associated with a loss of land that was previously the property of the indigenous group. The peoples were often dispossessed of land by colonisers who used many tricks, but who also argued that this was "for the common good". When examining the objective hardships experienced by indigenous peoples, health is often one of the areas where they are most deprived.

In Australia, the life expectancy of Aboriginal men is about 50 years, approximately 30 years less than non-Aboriginal men. Tens of thousands of young Aboriginal children were taken from their families without consent (the "Stolen Generation"), told they were orphans or abandoned, and given to non-Aboriginal families to raise. In some Aboriginal communities hookworm, which is virtually unknown among white children and is easy to treat, is endemic. Unemployment among Aboriginals is $41 \%$, and is set to rise to $53 \%$ by 2006 . Australia is a "first world" country, has been wealthy for many years, has a powerful legal and parliamentary system, and a free press. In spite of this, the health and economic standards of its Aboriginal peoples can only be described as appalling. These statistics are reproducible to a greater or lesser extent in most countries, and are only more striking in Australia because Aboriginal peoples share a country with the non-Aboriginal population.

\section{Attitudes of indigenous peoples to the HGDP}

The Human Genome Diversity Project raises key questions, such as:

- who makes decisions with regard to medical research?

- who controls and plans medical research?

- who benefits from medical research?

- is it possible to offer "group rights" or "group approval"?

The HGDP targets indigenous peoples who have had little or no contact with other groups and who have not mixed their genes with others. The focus of the project to date has been in South America, but Northern Territory (Australia) Aboriginal groups have been approached for inclusion in the study.
The collected blood and tissue samples will bg placed in a biological DNA bank which will b류. used for research into disease susceptibility? Scientists hope that differences in susceptibilit between populations can be used to find genes, of genetically determined biochemical pathwayह which will give products for treating common dis eases. This has already been proven true for obes甲 ity. The project is largely funded by government and pharmaceutical companies. In exchange for technology and resources they are given access to the genetic raw material collected by researchers from Aboriginal groups; the HGDP functions an international marketplace for DNA samples.

History teaches us that the pure fascination of science cannot be quarantined from its broade social implications. The project has the potentiab to exploit the genomes of indigenous peoples as resource for multinational investment. This is nof only a denial of the rights of peoples to self-determination, but also an affront to huma ethics and to the dignity of all.

Examples have been quoted of blood samples having been taken on the pretext that these were for pathology tests of immediate clinical value, but the samples then being used to provide DN samples for the HGDP. Neither the immortalisa tion of the blood cells (which is an affront to the cultural values of many indigenous peoples) no the commercial potential of the samples is mact clear to those from whom the blood is taken. The scientists involved in some projects claimed that informed consent was not obtained because the tribal peoples involved would not understan DNA research, so there was no use providing explanations, although they then claimed tha consent was obtained "in as much as they could

Suppose such standards were applied in othe situations in Australia, or other first world countries. Would working-class people be abusee like this, and be informed "in as much as the could"? Would this standard be applied to those Irish, or Italian, or Jewish ethnicity in Australia, of is the standard for indigenous peoples clearly lower than for others? Are the Arhuacos, Assarion and Guayami peoples treated differently because of their ethnicity, and afforded fewer rights because of these differences? Is it all right to tak their blood with only a condescending commerif and no informed consent, when laws prevent blood sampling from suspects of the most seriot crimes, from the mentally ill or from childrers Does anyone seriously believe that white people first world countries could be treated like this?

In a recent article Juengst states that it is no् possible to offer any protection to autonomo groups by obtaining approval from them prior 
genetic studies, and that even requesting such approval risks encouraging the discriminatory attitudes which it seeks to oppose. ${ }^{7}$ Juengst also claims that there are enough people from any ethnic group who have migrated so that at least a few would be willing to give DNA samples (either voluntarily or for payment) without worrying about the attitudes of the group as a whole.

While Juengst might be correct, at least in part, he ignores the fact that an indigenous people is not merely a group in the population genetics sense, but also a group in that its members are victims of institutionalised discrimination. It is discrimination against an ethnic group which is central to the ethical issue. Although individual Catholics, for example, may be discriminated against in the United States, it would be absurd to compare their situation with that of the Native American peoples or the Australian Aborigines, and therefore the same ethical issues of group consent do not apply. While Juengst may state accurately that it is possible to circumvent a mechanism for appropriate and equal dealing and consultation, it would be unethical to do so. The article following that of Jeungst in the American fournal of Human Genetics reports use of a model agreement for genetic research with a Native American tribe which shows the value of such an approach. ${ }^{8}$

As presently structured, many interactions of genome scientists with indigenous peoples see them as a means to an end. Researchers take blood and go back into their laboratories, remaining immune to the reality of the human suffering experienced on a daily basis by indigenous peoples. Researchers may come face to face with poverty and deprivation when they collect samples, and can recount these stories at dinner parties, but remain untouched in real terms, because they are inactive at correcting these injustices. Because they do little or nothing to facilitate change, they contribute to the continuation of the shameful status quo. (There are exceptions to this generalisation-for instance, the research team which collected Huntington's disease DNA samples from Venezuela has taken an active responsibility for improving health care for the affected population, as has Dr Sheila van Holst-Pelikaan in Western New South Wales-but they are few and far between.)

It is perhaps ironic that it has been estimated that it costs approximately US\$2,300 to collect each blood sample for the Human Genome Diversity Project. This is more than the per capita Gross Domestic Product (GDP) of most of the world. Perhaps at least some of this money could be spent attempting to ensure that indigenous peoples are not seen only as "isolates of historic interest", and to support their attempts to survive in their integrity.

\section{Is there a way forward?}

We need to work out an ethical and realistic way to negotiate issues such as control over research ownership. It is clearly not reasonable to insist that indigenous peoples are the sole beneficiaries of the benefits that flow from research; were this the case much research would never get done. However, benchmarks must be set out clearly. The rights of indigenous peoples over their resources (including their genetic resources) must be recognised, protected and respected.

It seems to us that the first fundamental ethical imperative is that those who wish to obtain biological samples from any ethnic group must begin by making an effort to understand their situation and culture and by respecting their concept of autonomy and their belief system. In the case of most indigenous peoples, this means accepting that there may be a strong sense of common ownership and cultural identity which does not allow an individual to part with something such as DNA, whether for money or other reasons, without group consent. Scientists have to negotiate such issues with equality and respect, and accept answers that they may not like. If the result of such negotiations is that research does not proceed, so be it; this often happens in other contexts when a human ethics committee blocks a clinical trial on patients. It may be argued that research will not progress as quickly as it otherwise might, but this is often the outcome of accepting ethical constraints in medical contexts.

If a situation of oppression exists which affects a group, it is imperative in terms of justice that we condemn such a situation and work towards its amelioration and elimination. Naturally, indigenous peoples know, as we all do, that there are many situations of injustice and oppression in the world, and no one has the personal energy or financial resources to deal with them all, nor can any individual be expected to. If scientists ask indigenous peoples who are in such a situation for their support in research, they have an obligation to offer their support in turn to help efforts to improve the economic and political situation of the group with which they work.

There is an additional ethical obligation which would occur if the scientific research for which the samples are needed is likely to produce a "for profit" product. This concerns justice. Consider a scientific project where three groups collaborate, each bringing something important to the work one brings the starting material in the form of 
DNA or clones or clinical picture, the second a technique for analysis, the third an ability to carry out development and patent a product. If there is an outcome, all three groups would expect to share in it, whether as authors of scientific papers, or shares of research grants, or a proportion of product revenue. It would be unjust if this were not the case. The indigenous group which is to be studied for, say, genes which predispose to diabetes regards itself (rightly) as part of those who bring essential starting material to the project - their genetic heritage. They have been told this by the scientists, as the rationale for requesting their cooperation in the project. They then find that everyone else seems to benefit - the scientists get grants and papers, the biotech companies get patents and issue shares, and (eventually) the big pharmaceutical companies may bring out a product which makes money. What, exactly, flows back to the affected indigenous group? They are still impoverished and disenfranchised, and their health status is no better than when they agreed to give the samples. The empowered group uses the knowledge to improve their health, but little if anything of this benefit comes to those who gave the raw material used to make the discovery.

We know this is oversimplified-in particular, the commercial significance of a gene discovery is easily overestimated, and the bulk of the inventive process takes place after the gene analysis. However, from the ethical point of view it is unjust that one partner receives so little when its need is so much greater than that of the other partners.

We believe that this problem is soluble. The indigenous group must be taken into the confidence of the researchers, and of those who fund the work. Both the levels of funding and the uncertainties of outcome must be discussed. This is not simple, but honest and equal discussion, which may need to take place over time and with people who are suspicious due to their experience, is essential. Indigenous peoples who provide key material for a project have a right to share in the long term profit which accrues from that project's outcome, even if it is many years in coming. Protocols that outline these principles may be useful in helping all of those involved to ensure that issues are fully discussed and understood.

Practical improvements (such as the provision of a district nursing service to a deprived community) may be regarded as an embodiment of commitment which speaks louder than talk about benefits to humanity. Those in pain often have a more immediate and personal view of benefits to humanity than others, and ask that such benefius start with those in greatest need. Although th represents a breach of the principle that \&ll $_{1}$ participation in research is strictly voluntary ant not dependent on remuneration, in this conteft the group that has been previously disadvantagef receives the benefit as a people. This alters the ethical dimension as there is no personal gain an individual.

The scientific community should have the humility to accept that, however good the intentions, the HGDP did not start with the co $\overrightarrow{\mathrm{r}}$ rect approaches to nor respect for indigenows peoples in many cases. It is the scientific comm nity that has the ethical obligation to start agaip, and to offer proper explanations in a context of respectful negotiation and a commitment equality.

\section{Acknowledgments}

Portions of this contribution are based on $\frac{7}{7}$ lecture given to the Human Genetics Society of Australasia by Michael Dodson (as Aborigingi and Torres Straits Islander Social Justice Corp missioner of the Human Rights and Equad Opportunities Commission) on "Indigenous $S \&$ cial and Ethical Issues: Control of Research ar鹿 Sharing of Benefits", July 1995, in press. The authors hope that this article will form part of the ongoing process of honest and sincere reconcilis tion between indigenous people, and newcome in Australia.

Michael Dodson, B Furis, $L L B, P h D$, is Director of Indigenous Law Centre, University of New Sough Wales, Sydney, New South Wales, Australia. Robe⿳⺈⿴囗十灬⿺𠃊t Williamson, PhD, FRCPath, FRCP (Edin), is Direo tor of The Murdoch Institute, Royal Children's Hosp tal, Melbourne, Australia.

\section{References}

1 Wadman M. Human genome deadline cut by two years. Nat 1998;395:207.

2 Evans L. The Human Genome Diversity project [summary dộ ment]. London: Human Genome Organisation, 1993.

3 National Research Council (United States of America).Evalts ating human genetic diversity. Washington DC: National
Academy Press, 1997.

4 Harding RM, Sajantila A. Human genome diversity $\widetilde{C}^{a}$ project? Nature Genetics 1998;18:307-8. 5 Roberts L. A genetic survey of vanishing peoples. Science 19 क्ष;;
252:1614-17.

6 Mooney PR. The gene piracy. Frontline 1994 Jul 29: 91-4.

7 Juengst E. Group identity and human diversity: keeping biology straight from culture. Amercan fournal of Hum Genetics 1998; 63:673-7.

8 Foster MW, Bernsten D, Carter TH. A model agreement genetic research in socially identifiable populations. American fournal of Human Genetics 1998 63:696-702. 